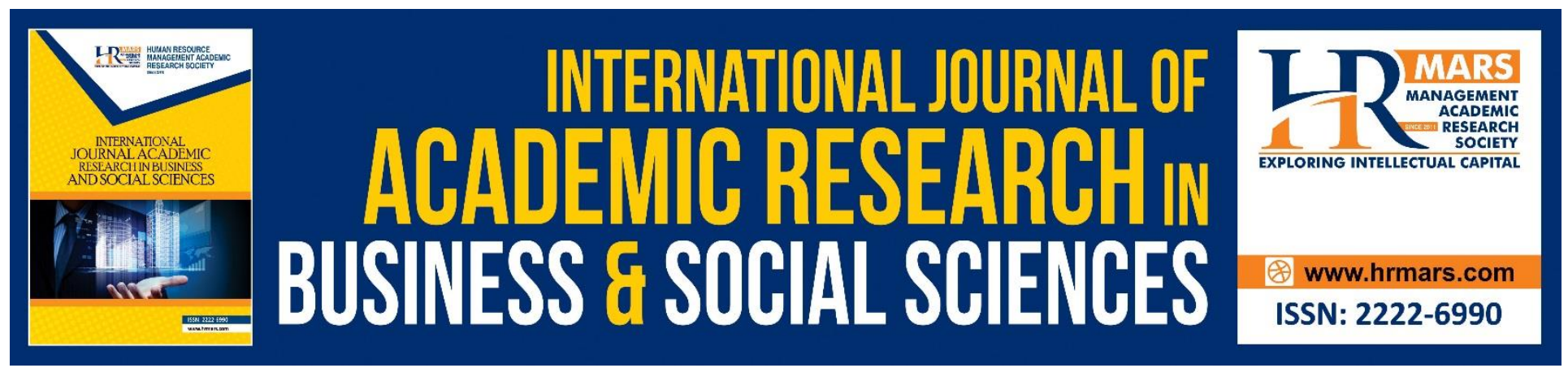

\title{
Confirmatory Factor Analysis: Teacher Leadership Measurement Model
}

Normah Karmani, Jamal @ Nordin Yunus

To Link this Article: http://dx.doi.org/10.6007/IJARBSS/v10-i7/7598

DOI:10.6007/IJARBSS/v10-i7/7598

Received: 09 May 2020, Revised: 14 June 2020, Accepted: 24 June 2020

Published Online: 12 July 2020

In-Text Citation: (Karmani \& Yunus, 2020)

To Cite this Article: Karmani, N., \& Yunus, J. @ N. (2020). Confirmatory Factor Analysis: Teacher Leadership Measurement Model. International Journal of Academic Research in Business and Social Sciences, 10(7), 697-706.

\section{Copyright: (C) 2020 The Author(s)}

Published by Human Resource Management Academic Research Society (www.hrmars.com)

This article is published under the Creative Commons Attribution (CC BY 4.0) license. Anyone may reproduce, distribute, translate and create derivative works of this article (for both commercial and non-commercial purposes), subject to full attribution to the original publication and authors. The full terms of this license may be seen

at: http://creativecommons.org/licences/by/4.0/legalcode

Vol. 10, No. 7, 2020, Pg. 697 - 706

http://hrmars.com/index.php/pages/detail/IJARBSS

JOURNAL HOMEPAGE

Full Terms \& Conditions of access and use can be found at http://hrmars.com/index.php/pages/detail/publication-ethics 


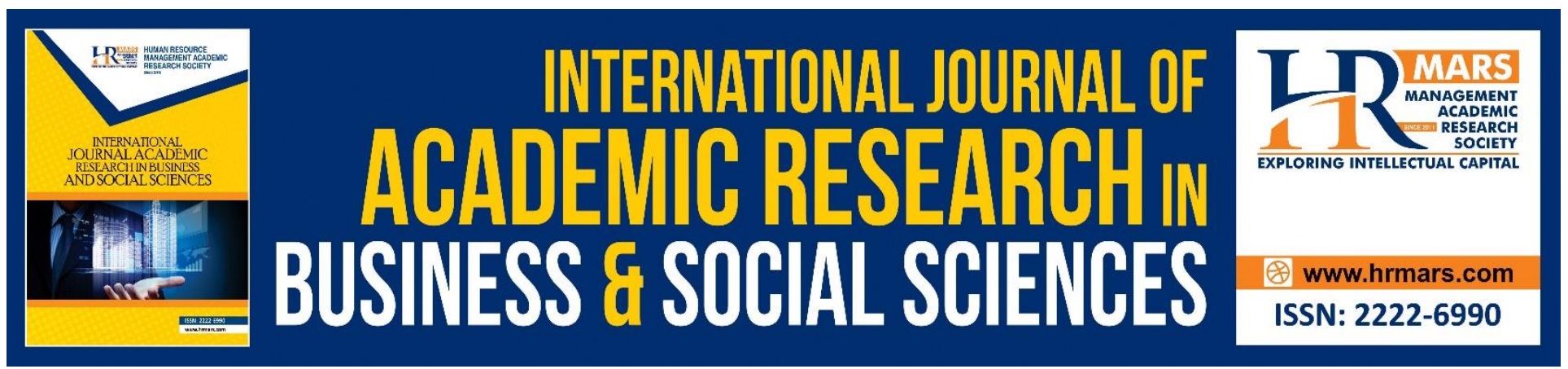

\title{
Confirmatory Factor Analysis: Teacher Leadership Measurement Model
}

\author{
Normah Karmani, Jamal @ Nordin Yunus \\ Faculty of Management and Economics, Universiti Pendidikan Sultan Idris, 35900 Tanjong Malim, \\ Perak, Malaysia
}

\begin{abstract}
The purpose of this study was to describe a construct validation study of Teacher Leadership among secondary school teachers in Malaysia. This study used a confirmatory factor analysis method (CFA) to analyze the measurement model of this study. Participants included daily secondary school teacher in the state of Selangor, Malaysia involved in this study. Confirmatory factor analysis (CFA) was employed and carried out to verify the instrument of Teacher Leadership. The respondents were required to respond to a seven-point Likert scale in semantic differential form. The collected data were then analyzed using the SPSS23.0 and AMOS23.0 software packages. An exploratory factor analysis was conducted earlier than performing a confirmatory factor analysis. All constructs revealed the acceptable internal consistency reliability. A good model fit was found for the measurement model using several fit index tests like CMINDF, TLI, GFI, AGFI, CFI and RMSEA. The findings showed that all fit indices criteria were accomplished. It also showed the acceptable reliability and construct validity. The implication of this study is expected to provide additional information in the teacher leadership theory and provide a clear line of training and professionalism enhancement programs for teachers, schools and the Ministry of Education Malaysia.
\end{abstract}

Keywords: Confirmatory Factor Analysis (CFA), Teacher Leadership, Measurement Model, Validity, Index Fit.

\section{Introduction}

Over the past decade, teacher leadership strategies have been an important aspect of improving student performance through improving teaching and learning by teachers. However, teacher leadership is not only focused on teaching and learning in the classroom, but its role is seen beyond the classroom; influencing decision making and emphasizing aspects of organizational support. In addition, peer support and the administration line are seen as helping teachers develop greater knowledge, skills, confidence and impact on school development (Meirink et al., 2019; Poekert, Alexandrou, \& Shannon, 2016; York-Barr \& Duke, 2004). In addition, the combination of research and education policy is increasingly playing a role in utilizing teachers' leadership capabilities in strengthening teaching and learning in the classroom in line with current educational goals, especially 
in improving the quality of education at the international level of education. The Ministry of Education must take drastic steps to strengthen teacher leadership as one of the agents of education transformation of the country. Therefore, the action of the Ministry of Education in Education Development Plan 2013 -2025 in Wave 3 (2021 - 2025) emphasizes that cultural aspects of excellence in colleague-based teacher professionalism is a necessary step in realizing the ministry's desire to improve the quality of national education (Ministry of Education, 2012). Therefore, the development of teacher leadership models is necessary, in line with the need to produce high quality teachers coinciding with international quality education goals (Sherinawani, Asri, Rohaila, \& Hamidah, 2015; Abu Bakar, Basri, \& Fooi, 2015).

Studies on the development of teacher leadership models are not foreign to the east although previous studies on instrument development have been conducted in the west either using quantitative or qualitative approaches or mix methods. Most researchers place collaborative criteria among teacher leaders as catalysts in improving teacher leadership (Flood \& Angelle, 2017; Sterrett \& Irizarry, 2015; Tsai, Padre, \& Pereira, 2017). However, teacher leadership not only supports professional learning of fellow teachers but also influences decision making. School administration structures including principals are also key contributors to building teacher leadership. Overall, teacher leadership encompasses not only individual aspects of teacher leadership but also school climate and culture; aimed at enhancing school achievement and transformation (Angelle, 2017; Hunzicker, 2017; Wenner \& Campbell, 2016). Therefore, there is a challenge to build a good model of teacher leadership with high validity and reliability so that it can be used to measure teacher leadership among teacher leaders.

The present model of teacher leadership has used Theory of Teacher Leadership developed by Barr and Duke (2004) and the Teacher Leadership Sphere Model (Fairman \& Mackenzie, 2014) as the basis for this model. Based on Theory of Teacher Leadership Theory by York Barr and Duke (2004) and the Sphere Model of Teacher Leadership Actions (Fairman \& Mackenzie, 2014), it is found that improving teaching practice is a key aspect of teacher leadership. Both models also agree that organizational development and teacher collaboration support the development of teacher leadership models. However, the Sphere Model of Teacher Leadership Action (Fairman \& Mackenzie, 2014) found that teacher leaders expanded the role of collaboration not only among teachers but also with parents, the community, external organizations and the professional community. In addition, teacher leaders are also seen as experts in sharing their knowledge and experiences. The development of a Teacher Leadership Measurement Model that impacts student and school improvement is necessary to provide a more comprehensive understanding of teacher leadership. To date, there have been few studies on the development of teacher leadership models conducted especially among teacher leaders in Asia. The purpose of this study was to develop a model of teacher leadership that has high validity and reliability among daily secondary school teacher leaders in the state of Selangor, Malaysia. This model of teacher leadership measurement was conducted using confirmatory factor analysis (CFA).

\section{Teacher Leadership}

The Teacher Leadership Instrument for measuring teacher leadership among schoolteachers in Malaysia consists of six sub-constructs with 29 items. The six sub-constructs are Leading the teaching and learning, Become role model, Leading school development, Peer collaboration, Working with 
INTERNATIONAL JOURNAL OF ACADEMIC RESEARCH IN BUSINESS AND SOCIAL SCIENCES Vol. 10, No. 7, July, 2020, E-ISSN: 2222-6990 @ 2020 HRMARS

parents and community, and finally Exemplary. Each of the six sub constructs has its own items for measuring the construct as shown in Table 1.

Table 1. Table of items and sub-constructs of Teacher Leadership instruments

\begin{tabular}{|l|l|l|}
\hline Bil & Sub Constructs of Teacher Leadership & Item \\
\hline 1. & Leading the teaching and learning & $1,2,3,4,5,6$ \\
\hline 2. & Become role model & $7,8,9,10,11$ \\
\hline 3. & Leading school development & $12,13,14,15$ \\
\hline 4. & Peer collaboration & $16,17,18,19,20,21$ \\
\hline 5. & Working with parents and community & $22,23,24,25$ \\
\hline 6. & Exemplary & $26,27,28,29$ \\
\hline
\end{tabular}

The seven-point scale was used in this survey using the scale (1) "strongly disagree" until scale (7) "strongly agree". Researchers chose the seven-point scale because the Likert scale of four points and above is suitable for factor analysis (EFA) as well as confirmatory analysis (CFA) (Chua, 2009; Dawes, 2008). Researchers used a seven-point Likert Scale with semantic differential words that had adjectives at both ends of the scale. Researchers are able to obtain information from respondents more precisely because of the more sensitive scale of these semantics (DeVellis, 2003).

\section{Validation of Measurement Model}

The researcher used confirmatory factor analysis (CFA) to analyze the fit of the Teacher Leadership measurement model among daily secondary school teachers in the state of Selangor, Malaysia. CFA analysis was used to validate the items in measuring the constructs of this study (Hair, Black, Babin, \& Anderson, 2010). The sub-constructs and items created in this Teacher Leadership study are based on theory and literature studies and can be tested against sample data.

A total of 348 daily secondary school teachers in Selangor, Malaysia participated in this study. At least 200 respondents were required to perform CFA analysis. Therefore, a total of 348 respondents in this study were adequate (Hair, Money, Samouel, \& Page, 2007). Normalized scattering data with skewness and kurtosis values between +1 and -1 values (Hair et al., 2010) is a requirement that must be met in CFA analysis. Determinants of uni-dimensionality, validity and reliability were conducted in this Confirmatory factor analysis (CFA).

\section{(i) Uni-dimensionality}

Uni-dimensionality refers to each indicator contained in only one factor. Uni-dimensionality can be shown when there is no correlation of measurement error on each indicator. There are at least three items for each factor in this CFA analysis (Kline, 2011). Uni-dimensionality is achieved when the factor loading value is greater than 0.6 and for the newly constructed item factor loading value is above 0.6. The researcher had to drop Items with a factor loading of less than 0.5 in this analysis (Hair et al., 2010).

\section{(ii) Validity}

Validity is the ability of an instrument to measure what to measure (Kerlinger, 1986). There are three types of validity required for this measurement model namely: 
INTERNATIONAL JOURNAL OF ACADEMIC RESEARCH IN BUSINESS AND SOCIAL SCIENCES Vol. 10, No. 7, July, 2020, E-ISSN: 2222-6990 @ 2020 HRMARS

\section{(a) Convergent Validity}

Convergent validity shows that the correlation value of a measure with the predicted size is theoretically correlated. Focusing accuracy is achieved when all items of measurement model are in significant condition. Validity is demonstrated when all constructs have a AVE value of greater than 0.5 (Hair et al., 2010).

\section{(b) Construct Validity}

Construct validity refers to the item representing the construct to be measured. Construct validity is achieved when meeting the model fit index for the construct (Kline, 2011). The three categories of model fit in the measurement model are absolute fit, incremental fit and parsimonious fit as shown in Table 2.

Table2. Index Category and Acceptance Value for Each Index

\begin{tabular}{|l|l|l|}
\hline Category & Index & $\begin{array}{l}\text { Acceptance } \\
\text { Value }\end{array}$ \\
\hline 1. Absolute Fit & Chisq(Discrepancy Chi Square & $P>0.05$ \\
\hline & $\begin{array}{l}\text { RMSEA(Root Mean Square of Error } \\
\text { Approximation) }\end{array}$ & RMSEA $<0.08$ \\
\hline & GFI(Goodness of Fit) & GFI $>0.90$ \\
\hline 2. Incremental fit & AGFI(Adjust Goodness of Fit) & AGFI $>0.90$ \\
\hline & CFI(Comparative Fit Index) & CFI $>0.90$ \\
\hline & TLI(Tucker-Lewis Index) & TLI $>0.90$ \\
\hline & NFI(Normed Fit Index) & NFI $>0.90$ \\
\hline 3. Parsimonious fit & Chisq/df(Chi Square/Degrees of Freedom) & Chi/df $<5.0$ \\
\hline
\end{tabular}

Source : (Hair et al., 2010)

\section{(c) Discriminant Validity}

Discriminant validity, on the other hand, argues that constructions are not correlated with other constructs in theory. Discriminant validity of high values indicates that the construct is unique. If the correlation value between the two latent variables exceeds 0.9 then it indicates that there is overlap between the constructs (Hair et al., 2010).

\section{(iii) Reliability}

Reliability coefficient refers to the internal consistency measure of the construct referring to the uniformity of the latent variables and the construct validity studied (Hair et al., 2010). Once the model has reached an index value of compatibility then the reliability and validity of the construct can be determined.

Internal Validity, Composite Reliability, and Average Variance Extracted (AVE) need to be achieve to meet the reliability of a measurement model. The reliability of a measurement model is achieved when Internal reliability is met. Composite Reliability is met when the Composite Reliability (CR) value is at or above 0.6. Average Variance Extracted (AVE) is achieved when AVE values are equal to 0.5 or greater to prove adequate convergent validity (Hair et al., 2010). 
INTERNATIONAL JOURNAL OF ACADEMIC RESEARCH IN BUSINESS AND SOCIAL SCIENCES

Vol. 10, No. 7, July, 2020, E-ISSN: 2222-6990 @ 2020 HRMARS

\section{Steps to Verify Teacher Leadership Skill Measurement Model}

The researcher has taken several steps to validate this Model of Teacher Leadership. Researchers begin CFA analysis by looking at the model fit index. If the model fit index is not reached, the researcher will drop an item that has a Factor Loading value of less than 0.5 . The process of dropping an item is done one by one by dropping the lowest factor load. Researchers will look at the Modification Indices (MI) if the model's compatibility index level is not reached. Items with high MI values will be removed. Researchers also should ensure that there is no overlap of items between constructs. Sub constructs are aggregated if the correlation value exceeds 0.9 between the two sub constructs. Finally, researchers need to obtain the reliability of this measurement model by obtaining Cronbach's Alpha, CR and AVE values (Kline, 2011; Zainuddin, 2012).

\section{Results}

Figure 1 shows the CFA analysis of the teacher leadership measurement model. The Teacher Leadership Measurement Model has four latent variables, namely, Working with Parents and Communities (IBKOM), Exemplary (DTL), Peer Collaboration (KOLB) and Leading School Development (PBGSK). 
Chi-square $=105.746(\mathrm{df}, \mathrm{p}$-value $=.000)$

Normed Chi-square $=2.203$ [1 to 5]

$\mathrm{CFI}=.979$ [>0.09], RMSEA=.059[0.08]

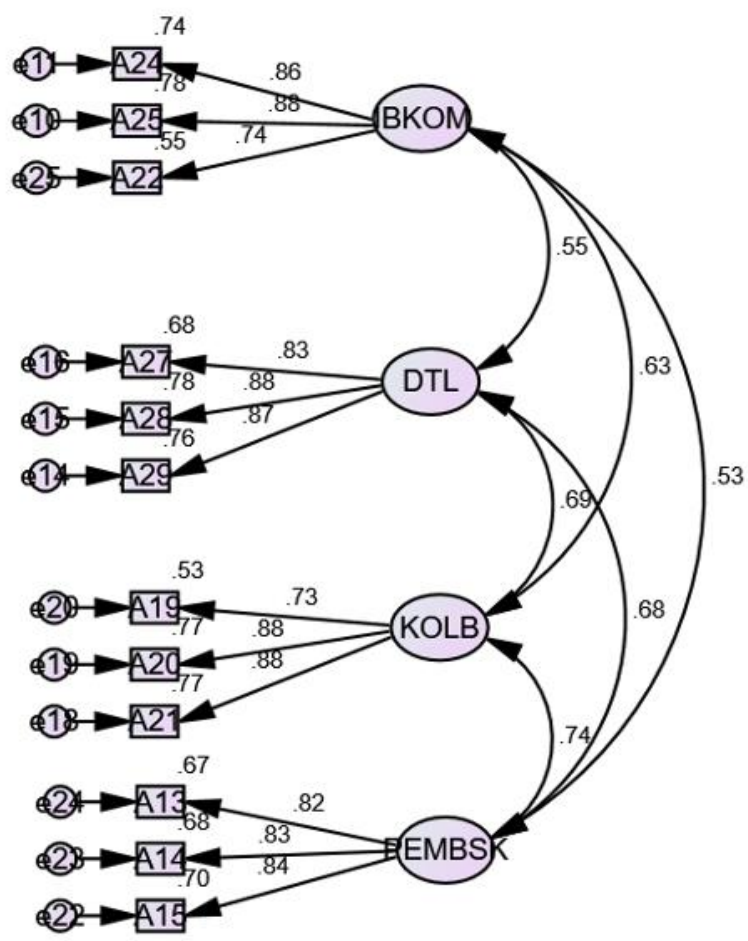

Figure 1. Teacher Leadership Measurement Model

\section{Goodness of Fit Indices}

CFA (Confirmatory Factor Analysis) analysis showed that all sub-constructs qualify as the model of Teacher Leadership measurement as shown in Figure 1. Goodness of fit indices has been met as shown in Table 3. 
INTERNATIONAL JOURNAL OF ACADEMIC RESEARCH IN BUSINESS AND SOCIAL SCIENCES Vol. 10, No. 7, July, 2020, E-ISSN: 2222-6990 @ 2020 HRMARS

Table 3. Index Category and Acceptance Value of Each Construct in Teacher Leadership Model

\begin{tabular}{|l|l|l|l|}
\hline Category & Index & $\begin{array}{l}\text { Acceptance } \\
\text { Value }\end{array}$ & $\begin{array}{l}\text { Teacher Leadership } \\
\text { Model }\end{array}$ \\
\hline 1. Absolute Fit & $\begin{array}{l}\text { Chisq (Discrepancy } \\
\text { Chi Square) }\end{array}$ & $P>0.05$ & P-Value $=.000$ \\
\hline $\begin{array}{l}\text { RMSEA (Root Mean } \\
\text { Square of Error } \\
\text { Approximation) }\end{array}$ & RMSEA $<0.08$ & RMSEA $=0.059$ \\
\hline & $\begin{array}{l}\text { CFI (Comparative Fit } \\
\text { Index) }\end{array}$ & CFI $>0.90$ & CFI $=0.979$ \\
\hline $\begin{array}{l}\text { TLI (Tucker-Lewis } \\
\text { Index) }\end{array}$ & TLI $>0.90$ & TLI $=0.971$ \\
\hline 3. Parsimontal fit (Normed Fit & NFI $>0.90$ & NFI $=0.962$ \\
Index) & $\begin{array}{l}\text { Chisq/df (Chi } \\
\text { Square/ Degrees of } \\
\text { Freedom) }\end{array}$ & Chi/df $<5.0$ & Chi/df $=2.203$ \\
\hline
\end{tabular}

Source: (Hair et al., 2010)

\section{Validity and Reliability of Teacher Leadership Construct}

Validity is accepted when the convergent validity and construct validity is achieved. The standardized factor loading of each item for the accepted construct is shown in Table 4.

Table 4. Loading Factor, Cronbach's Alpha dan AVE Teacher Leadership Model

\begin{tabular}{|c|c|c|c|c|c|}
\hline Construct & Item & $\begin{array}{l}\text { Loading } \\
\text { Factor }\end{array}$ & $\begin{array}{l}\text { Cronbach's } \\
\text { Alpha } \\
(>0.7)\end{array}$ & $\begin{array}{l}\text { CR (Composite } \\
\text { Reliability) } \\
(>0.6)\end{array}$ & $\begin{array}{l}\text { AVE (Average } \\
\text { Variance Extracted) } \\
(>0.5)\end{array}$ \\
\hline \multirow{3}{*}{$\begin{array}{l}\text { Working with } \\
\text { Parents and } \\
\text { Community } \\
\text { (BKOM) }\end{array}$} & A24 & 0.86 & 0.863 & 0.867 & 0.687 \\
\hline & A25 & 0.88 & & & \\
\hline & $\mathrm{A} 22$ & 0.74 & & & \\
\hline \multirow[t]{3}{*}{ Examplary (TDL) } & $\mathrm{A} 27$ & 0.83 & 0.894 & 0.895 & 0.740 \\
\hline & A28 & 0.88 & & & \\
\hline & A29 & 0.87 & & & \\
\hline \multirow{3}{*}{$\begin{array}{l}\text { Peer } \\
\text { Collaboration } \\
\text { (KOLB) } \\
\end{array}$} & A19 & 0.73 & 0.859 & 0.869 & 0.689 \\
\hline & A20 & 0.88 & & & \\
\hline & A21 & 0.88 & & & \\
\hline \multirow{3}{*}{$\begin{array}{l}\text { Leading School } \\
\text { Development } \\
\text { (PEMBSK) }\end{array}$} & A13 & 0.82 & 0.868 & 0.868 & 0.686 \\
\hline & A14 & 0.83 & & & \\
\hline & A15 & 0.84 & & & \\
\hline
\end{tabular}

Convergent validity is obtained when the AVE (Average Variance Extracted) value is greater than 0.50 (Hair et al., 2010). The AVE value of all constructs of teacher leadership model are in AVE> 
INTERNATIONAL JOURNAL OF ACADEMIC RESEARCH IN BUSINESS AND SOCIAL SCIENCES Vol. 10, No. 7, July, 2020, E-ISSN: 2222-6990 @ 2020 HRMARS

0.50 where BKOM (0.687), DTL (0.740), KOLB (0.689) and PEMBSK (0.686) that are shown in Table 4. The previous Table 3 indicates that the Construct Validity test is satisfied when this Teacher Leadership construct meets the model fit indexes.

Reliability tests are also accepted when internal reliability, composite reliability and average extracted variance are achieved. Based on Table 4, all sub-constructs showed high internal reliability with Cronbach's Alpha values above 0.70 . CR (composite reliability) is accepted when all constructs show a CR value greater than 0.60. Average extracted variance (AVE) was also accepted because all sub-constructs showed AVE values above 0.50 .

\section{Conclusion and Future Agenda}

This study shows the development of a Teacher Leadership Measurement Model that can help provide additional information to educators in education management as well as policy makers in the Ministry of Education. This study provides evidence that the Teacher Leadership have four constructs - Collaborating with Parents and Communities, Exemplary, Peer Collaboration, and Leading School Development. The findings suggest that teacher leadership needs to be nurtured by applying the knowledge and skills of teacher leadership to optimize teacher competence in today's era of globalization of education. The purpose of this study is to add information to the theory of teacher leadership in order to improve the level of teacher leadership in school. The findings of the study also help the Ministry of Education Malaysia to provide training and programs to enhance professionalism for teachers and schools.

\section{Correspondent Author}

Jamal @ Nordin Yunus, PhD in Educational Management at Universiti Utara Malaysia 2008. He was appointed Lecturer since 2000 at Universiti Pendidikan Sultan Idris. Has the experience of teaching several courses in Management and Educational Leadership. Amongst these courses are: Action Research, Supervision and Instructional, Research Methodology, Applied Statistics, Learning organization in education, Curriculum and instructional design, Administration and Management education and Critical and Creative Thinking

\section{References}

Angelle, P. S. (2017). Leading Beyond the Classroom. International Studies in Educational Administration (Commonwealth Council for Educational Administration \& Management, 45(3), 101-107.

Chua, Y. P. (2009). Statistik penyelidikan lanjutan: Ujian regresi, analisis faktor dan analisis SEM. Buku 5. Malaysia: McGraw-Hill.

Dawes, J. (2008). Do data characteristics change according to the number of scale points used ? International Journal of Market Research, 50(1), 61-78.

DeVellis, R. F. (2003). Scale development : Theory and applications. (Second edd). United Kingdom: SAGE Publication,Inc.

Fairman, J. C., \& Mackenzie, S. V. (2014). How teacher leaders influence others and understand their leadership. International Journal of Leadership in Education, (August), 1-27.

Flood, L. D., \& Angelle, P. S. (2017). Organizational Influences of collective efficacy and trust on teacher leadership. International Studies in Educational Administration (Commonwealth Council for Educational Administration \& Management (CCEAM)), 45(3), 85-100. 
INTERNATIONAL JOURNAL OF ACADEMIC RESEARCH IN BUSINESS AND SOCIAL SCIENCES

Vol. 10, No. 7, July, 2020, E-ISSN: 2222-6990 @ 2020 HRMARS

Hair, J. F., Black, W. C., Babin, B. J., \& Anderson, R. E. (2010). Multivariate data analysis (7th ed.). New Jersy: Prentice-Hall.

Hair, J. F., Money, A. H., Samouel, P., \& Page, M. (2007). Research methods for business. England: John Wiley \& Son Ltd.

Hunzicker, J. (2017). From Teacher to Teacher Leader: A conceptual model. International Journal of Teacher Leadership, 8(2), 1-28.

Kerlinger, F. N. (1986). Foundation of behavioral research. New York: Rinehart \& Wiston.

Kline, R. B. (2011). Principles and practice of structural equation modeling (3rd ed.). New York: The Guilford press.

Meirink, J., Van Der Want, A., Louws, M., Meijer, P., Oolbekkink-Marchand, H., \& Schaap, H. (2019). Beginning teachers' opportunities for enacting informal teacher leadership: perceptions of teachers and school management staff members. European Journal of Teacher Education, 00(00), 1-15. https://doi.org/10.1080/02619768.2019.1672654

Ministry of Education. (2012). Pelan Pembangunan Pendidikan Malaysia 2013-2025.

Sherinawani, N. A. R., Asri, M. N., Rohaila, Y., \& Hamidah, Y. (2015). Kesahan model amalan kepimpinan guru. JuKu: Jurnal Kurikulum \& Pengajaran Asia Pasifik, 2(April).

Norashikin Abu Bakar, Ramli Basri, \& Fooi, F. S. (2015). Hubungan kepimpinan guru dengan pencapaian akademik pelajar. International Journal of Education and Training (InjET), 1(2), 111.

Poekert, P., Alexandrou, A., \& Shannon, D. (2016). How teachers become leaders: an internationally validated theoretical model of teacher leadership development. Research in Post-Compulsory Education, 21(4), 307-329. https://doi.org/10.1080/13596748.2016.1226559

Sterrett, W., \& Irizarry, E. (2015). Beyond " autopsy data ": Bolstering teacher leadership, morale , and school improvement. Journal of Cases in Educational Leadership, Vol. 18(1), 3 -13. https://doi.org/10.1177/1555458914551828

Tsai, K. C., Padre, A., \& Pereira, T. (2017). Development of the Teacher Leadership Style Scale, 45(3), 477-490.

Wenner, J. A., \& Campbell, T. (2016). The theoretical and empirical basis of teacher leadership : A review of the literature. Review of Educational Research, $X X(X), 1-38$. https://doi.org/10.3102/0034654316653478

York-Barr, J., \& Duke, K. (2004). What Do We Know About Teacher Leadership? Findings From Two Decades of Scholarship. Review of Educational Research.

Zainuddin, A. (2012). Structural equation modeling using Amos graphic. Shah Alam: Universiti Teknologi MARA Publication Center (UiTM Press). 